\title{
PENDIDIKAN MULTIKULTURAL TRANSFORMATIF KONSEP DAN APLIKASI
}

\author{
Isnarmi Moeis \\ Fakultas Ilmu Sosial Universitas Negeri Padang \\ aanisnarmi213@gmail.com \\ abstrak
}

Kerangka konseptual pendidikan multikultural tarnsformatif dikembangkan berdasarkan karakteristik keragaman bangsa Indonesia. Pendekatan pendidikan ini menggunakan pedagogi kritis yang menempatkan siswa bersama guru sebagai subjek belajar. Guru dan siswa bersama mengelola pembelajaran untuk memunculkan kesadaran tentang masalah-masalah yang menghambat terjalinnya hubungan sosial yang baik sebagai akibat proses pendidikan yang telah berlalu, dan bersama juga mereka merefleksikan keadaan tersebut, untuk menetapkan langkah perubahan yang lebih baik ke depannya. Pada akhirnya proses pendidikan ini memperkuat kompetenesi kultural subjek belajar sebagaimana yang dibutuhkan oleh bangsa Indonesia untuk mempertahankan persatuan dalam keragaman.. Penulisan ini merupakan tahap penelusuran teori untuk pengembangan disain Pendidikan Multikultural Transformatif, yang bersifat praktis. Tahap ini salah satu rangkaian penelitian R\&D yang menggunakan model ADDIE (Assesment, Design, Development, Implementation, Evaluation). Hasil yang dicapai dari penelusuran teoritis ini adalah bahwa pendidikan multikultural transformatif dikembangkan dengan kerangka berfikir pendidikan kritis yang dimulai dari to name, to reflec critically, and to act, sebagai cara membentuk kompetensi kultural.

Kata kunci ; pendidikan multikultural, pendidikan transformative, pedagogi kritis

\begin{abstract}
Conceptual framework of transformative multikultural education is developed based on uniqueness of Indonesian plural society. Critical pedagogy is the core approach of this education that placing teacher and student are subjects of learning. They carry out learning jointly, to generate the consciousness of .subjects about established reality, to reflect critically, to act meaningfully for making transformation. Therefore, transformative multikultural education is a away to build cultural competencies of Indonesian in order to live together in harmony.. This study is literature review to find out theoretical foundation developing a practical design of this multikultural education. The result of the study recommended that transformative multikultural education can be carried out based three steps of critical pedagogy : to name, to reflect critically, and to act .
\end{abstract}

Key words : multikultural education, transformative education, critical pedagogy

Biografi singkat penulis: Penulis adalah staf pengajar dan peneliti dalam bidang pendidikan multikultural dengan pespektif kritis. Tamatan S3 Universitas Pendidikan Indonesia, Bandung; Staf Pengajar pada prodi Pendidikan kewarganegaraan. Tertarik dalam kajian kritis terutama di bidang pendidikan multikultural dan telah dituangkan dalam bentuk buku dan tulisan ilmiah. 


\section{Pendahuluan}

Pada dasarnya pendidikan multikultural di Indonesia sangat dibutuhkan sesuai dengan amanah filosofis bangsa yang tersirat dalam Pembukaaan UUD 45 dan Pancasila, sebagai dokumen utama landasan normative berdirinya Negara Indonesia. Berdasarkan maksud dokumen tersebut bahwa Negara ini dibentuk di atas dasar kesatuan yang mencakup dan mengakomodir semua kemajemukan yang membentuk bangsa Indonesia. Amanah ini di rangkum dalam nilai dasar Pancasila sebagai Dasar Negara Indoneisa. Nilai-nilai itu dirumuskan dengan sifat umum, abstrak dan universal memberi peluang bagi semua keyakinan, dan kelompok etnis untuk hidup berdampingan dalam kebersamaan yang diikat oleh Negara Kesatuan Republik Indonesia. Dengan merujuk kepada pendapat Notonagoro (dalam Moeis 2014) tentang isi Pancasila yang menunjukan hakikat kemanusian yang mono pluralis (satu tapi jamak), substansi Pancasila mencerminkan hakikat kemanusiaan dalam kerangka kodratiah bahwa manusia adalah makhluk individu dengan atribut yang jamak. Dalam ketunggalan manusia terdiri atas sifat jasmaniah dan ruhaniah, disamping sifat personal dan sosial, serta sifat sebagai pribadi mandiri dan sekaligus ciptaan Tuhan. Pengakuan terhadap kemajemukan nilai kemanusiaan ini secara tegas menjadi pandangan dasar tentang nilai yang membentuk Pancasila sebagai dasar Negara. Jika diterjemahkan ke dalam nilai yang instrumental, terlihat bahwa hakikat kemanusian dalam konteks Negara Indonesia harus terwujud dalam bentuk yang konkrit berupa pengakuan dan penyempurnaan sfat -sifat kemanusiaan yang tunggal dan majemuk. Berarti secara filosofis, Negara Indonesia memang dimaksudkan oleh para pendiri negara sebagai negara multikultural. Konsekwensinya pendidikan juga di arahkan membangun manusiamanusia multikultural. Ke-pluralan hakikat kemanusiaan secara lebih luas dapat diterjemahkan sebagai ke-pluralan masyarakat Indonesia yang menganut berbagai agama, serta tumbuh dan berkembang dalam berbagai tradisi (etnik, bahasa, dan adat istiadat) yang berbeda. Oleh karena itu dapat dikatakan kemajemukan bagi bangsa Indonesia merupakan kodrat kemanusiaan yang mengimplikasikan pengakuan secara luas dalam kehidupan berbangsa dan bernegara.

Amanah filosofis bangsa tersebut tidak terwujud dalam realita sosial kehidupan masyarakat Indonesia. Pemahaman tentang keragaman sering diterjemahkan dalam konteks kepentingan golongan, atau demi ekssitensi sebuah golongan dengan mengorbankan golongan lain. Fenomena ini berujung pada konflik antar golongan yang seolah tidak pernah berhenti mulai dari pertikiaan individu meluas jadi pertikaian kelompok seperti yang di Kalimantan, Poso, dan Maluku pada awal tahun 2000an hingga saat ini.. Menurut data statistic konflik massal di Indonesia (Statisktik Kriminal, Bappenas, 2014: hal 128) mengalami peningkatan yang cukup signifikan dari tahun ke tahun :

" selama tahun 2005 terjadi insiden perkelahian massal di sekitar 1.655 desa/kelurahan atau sekitar 2,37 persen dari jumlah seluruh desa/kelurahan di wilayah administratif Republik Indonesia. Insiden tersebut pada tahun 2008 semakin meningkat terjadi pada sebanyak 2.283 desa/kelurahan (3,03 persen). Seiring dengan meningkatnya kejadian kejahatan di berbagai wilayah di Indonesia, pada tahun 2011 kejadian perkelahian massal kembali merebak dan terjadi pada sebanyak 2.562 desa/kelurahan (3,26 persen). Kejadian perkelahian massal selama periode tahun 2005-2011 meliputi perkelahian antar kelompok warga, perkelahian warga antar desa/kelurahan, perkelahian warga dengan aparat, perkelahian antar pelajar dan perkelahian “

Bentuk konflik yang muncul berbagai macam dengan kemungkinan penyebab terjadinya konflik berakar pada berbagai persoalan. Seperti misalnya keterikatan terhadap tradisi seperti kasus di Ambon (Tri Ratnawati, 2003), dan terlebih lagi ketika pada saat yang sama kedua kelompok dituntut untuk mengorbankan tradisi demi toleransi yang ini merupakan pilihan yang sulit, sehingga dapat memicu konflik (Erni Budiwanti, 2003. Menurut analisis The World Bank (2004) tentang konflik lokal di Idonesia bahwa peningkatan jumlah suku, dan kepadatan tempat beribadah tidaklah 
menyebabkan konflik, tetapi keberadaan dan peran kelompok agama dan adat pada satu tempat memicu terjadinya konflik, disebabkan tidak adanya titik temu dalam norma yang sepadan untuk disepakati secara lintas kelompok bila terjadi pertikaian. Pada prinsipnya dalam semua bentuk konflik antar kelompok terdapat indikasi rendahnya toleransi dan kemauan untuk mengalah antar kelompok, dan serta kegagalan pemerintah mengkondisikan masyarakat untuk hidup berdampingan secara harmonis.

Patric Barron dan Joanne Sharpe (2008) berdasarkan analisis terhadap data konflik pasca Suharto, menyimpulkan beberapa tipe konflik yang terjadi di berbagai provinsi yaitu :1) konflik yang berkenaan dengan sumber daya alam (pertikaian tentang kepemilikan, penggunaan, serta akses), 2) konflik administratif (pertikaian tentang pengelolaan pemerintahaan, program yang didanai asing, dan pengelolaan badan usaha milik Negara, 3). konflik yang berkenaan pengaruh dan posisi politik terutama mengenai pemilu, 4), konflik berupa balas dendam, Sedangkan penyebab konflik terutama yang menyangkut konflik etnis - agama seperti di Maluku tidak bersifat tunggal sebagaiman analisis Wilson (2008), tetapi disebabkan oleh seperangkat mekanisme yang komplek dan proses yang tidak menentu sehingga konflik berkembang dari kecil menjadi besar hingga terjadinya eksploitasi politik dan perang agama. Satu hal yang menarik untuk diperhatikan bahwa konflik di Indonesia muncul kepermukaan bersamaan dengan transisi politik menuju demokrasi, setelah berada dalam pemerintahan yang sangat sentralistik, terpola, cenderung aman, tetapi (mengadung sisi negative) menonjolkan identitas nasional yang semu, terkesan mengabaikan identitas kelompok dan golongan (Schefold, 1998). Akhirnya mungkin bisa disimpulkan bahwa konflik antar kelompok menunjukan ketidaksiapan masyarakat dan juga pemerintah menyambut perubahan kehidupan yang lebih terbuka, beragam, dan setara.

Dari sudut pandang pendidikan, proses menuju bangsa yang harmonis memerlukan intervensi yang dirancang sebagai upaya penyadaran masyarakat dalam menyikapi perubahan. Dengan kata lain, peran pendidikan sangat dipelukan untuk merubah keadaan bila dilihat dari pergeseran pola pikir masyarakat dari monokultural menunju multikultural memerlukan fase-fase yang mencakup : monokultural > kontak antar budaya > konflik budaya > intervensi pendidikan > disequilibirium $>$ kesadaran (awareness) > multikultural (Nieto, 1992). Pendidikan merupakan dasar yang meletakan fondasi bagi anak untuk menuju kehidupan sosial dalam masyarakat yang beragam. Melalui pendidikan anak disadarkan tentang realita atau jati dirinya dan membangun konstruksi baru menghadapi keragaman di luar dirinya. Pendidikan harus mampu mepersiapkan anak menjadi agen perubahan yang bertanggungjawab secara personal, mampu berpartisipasi dalam tugas kemasyarakatan, dan berorientasi keadilan (Silva \& Day, 2011).

Pendidikan tidak hanya mengajarkan "word" tetapi terlebih dahulu mengajarkan siswa melihat "world" (Freire dalam Ritchie cs, 2013). Sebelum siswa belajar konten atau materi pembelajaran, mereka dibelajarkan terlebih dahulu untuk mempelajari konteks sosial, sejarah dan politik di mana mereka berada. Siswa tidak hanya berlajar disiplin ilmu tetapi mampu juga mengkritisi dengan kritis realita sosial di mana mereka berada. Mempelajari konten belum cukup untuk membuka kesadaran untuk perubahan. Paulo Freire (1921-1997) mengembangkan system pendidikan yang menempatkan perubahan sosial sebagai tujuan. Titik berangkat dari perubahan adalah penciptaan pengetahuan yang relevan, praktis dan memberdayakan. Penciptaan ini dikaitkan dengan mengkaji bentuk-bentuk opresi melalui analisis terhadap kekuasaan yang mendorong ketidak setaraan, dan membuka pengetahuan baru yang lebih memberdayakan pada tingkat individu atau kolektif (Tropiano,2008, ).

Adapun maksud dari tulisan ini adalah untuk mengurai landasan-landasan teoritis bagaimana konsep dan aplikasi pendidikan multikultural yang baik dikembangkan sebagai jawaban terhadap permasalahan bangsa yang semakin menjauh dari cita-cita Negara Kesatuan RI.

Moeis (2014) mengembangkan sebuah model konseptual pendidikan multikultural yang disebut dengan Pendidikan Multikultural Transformatif. Model ini dikembangkan berdasarkan atas penelitiaan (Moeis 2006) berkenaan dengan analisis terhadap konflik etnis di Indonesia di Ambon, Poso, dan Sambas yang terjadi sekitar tahun 1999 hingga awal 2000 an. Hasil penelitian menunjukan 
bahwa terjadinya pertikaian disebabkan dua hal : 1) Tingginya solidaritas kelompok, dan 2) sikap emosioal dan kehilangan daya kritis menyikapi isu yang bersebar. Fenomena ini terjadi karena sifat keragaman masyarakat Indonesia yang dicirikan dengan kuatnya ikatan internal, dan lemahnya interaksi eksternal, sehingga rendahnya interaksi lintas budaya antar kelompk yang berujung pada sikap saling mencurigai satu sama lain. Keadaan ini dimanfaatkan oleh pihak yang ingin melestarikan konflik sebagai upaya politis. Ketidak mampuan masyarakat membaca alur berfikir politik ini menyebabkan masyarakat kehilangan daya kritis untuk mencerna isu yang menyulut pertikaian antar golongan.

Berdasarkan analisis konflik tersebut telah dirumuskan satu model konseeptual yang memiliki dimensi nilai, dimensi pengembangan keilmuan, dan dimensi pedagogi. Dimenasi nilai mencakup : nilai ketaqwaan, nilai persatuan dalam bingkai NKRI, nilai keragaman budaya, supremasi hukum, dan kemanusian yang berkeadilan social. Pengembangan nilai dilakukan secara multisiplin, dengan perspektif local dan global. Target pendidikan adalh terjadinya perubahan pada diri subjek belajar, pada masyarakat, dan tataran Negara. Tujuan dari pendidikan untuk membangun kompetesni multikultural yang meliputi :1) penguatan jati diri, 2). Kemampuan interaksi sosial yang bersifat dialogis, kritis, berfikiran terbuka, dan 3) kemampuan bertindak secara adil.

Selanjutnya kajian-kajian teoritis dalam tulisan ini dimaksudkan sebagai fondasi keilmuan dari model, untuk selanjutnya dikembangkan menjadi disain praktis yang akan diimplementasikan.

\section{Metodologi}

Pengembangan kerangka koneseptual pendidian transformatif ini menggunakan model ADDIE yang banyak dipakai dalam pengembangan aktifitas pembelajaran di sector industri dan juga dilapangan pendidikan (Seda Khadimally, 2015) . Model ini terdiri dari lima langkah yang dihadirkan secara linear, yaitu Analysis - Design - Development - Implementation -Evaluation. Tahap analisis merupakan bagian penting yang menentukan bentuk disain, yaitu berdasarkan analisis konflik yang terjadi tahu 1999 hingga 2000an (Moeis, 2006) dikembangkan satu model konseptual pendidikan multikultural transformative. Untuk mengimplementasikan model perlu dikembangkan satu disain pendidikan multikultural transformative yang bersifat praktis. Satu langkah pengembangan disain adalah melalui penelusuran kepustakaaan untuk mendapatkan landasan teoritis yang jelas bagi penyunan disain. Tulisan ini adalah bagian dari kegiatan penelusuran teoritis tersebut. Hasil yang diharapkan adalah diperolehnya prinsip-prinsip dasar pendidikan multikultural dan rekomendasi arah pengembangan disain pendidikan multikulural transformative.

\section{Tinjauan Pustaka}

Asas dari pendidikan multikultural transformatif adalah perubahan diri dan perubahan sosial. Perubahan diri berawal dari kesadaran individu tentang hal-hal yang menyebabkan ketidak harmonisan hubungan sosial di sekitarnya, dan kemauan untuk memilah-milah penyebab dari diri dan di luar diri. Melalui proses interaksi dalam pembelajaran, individu merefleksi bahwa realita sosial sebagai produk yang berakar sebagian dari internal (dalam diri) dan sebagaian dari eksternal (orang lain). Asas ini bersifat personal, sosial dan kultural (Vygotsky, 1978; Bruner 1990). Dari diri yang berubah lahir pribadi yang berfikiran terbuka, rasional, berpengetahuan sehingga membentuk identitas diri yang secara personal memiliki nilai jati diri yang kuat, namun fleksibel menyikapi kondisi eksternal yang berbeda. Pribadi ini diharapkan menjadi pelopor yang mampu menciptakan suasana sosial yang harmonis, dan toleran. Pada tataran ini terjadinya perubahan sosial (Moeis, 2014). Pendididian transformatif menempatan aktifitas "dekonstruksi" ketidak berdayaan dalam realita diri subjek untuk kemudian membangun atau me"rekonstruksi" realitas baru yang kuat dan mampu menghadapi perbedaan. Aktifitas ini merupakan proses pembelajaran yang penting sebagai upaya membangun keasadaran, menciptakan makna, dan melakukan perubahan. (Mirza, 2011). Pendidikan multkultural transformatif menempatkan pembanguan kesadaran kritis sebagai sentral aktifitas 
pendidikan. Dalam hal ini diperlukan kemampuan dialog, pengungkapan masalah, dan eksplorasi tema-tema kritis berkaitan dengan isu perbedaan dalam masyaraat (Jayne R. Beilke, 2005).

Perubahan merupakan inti dari pendidikan transformatif. Pendididikan transformatif berarti adanya suasana belajar dengan proses kritis yang membawa seseorang ketingkat kesadaran dan menolak segala bentuk opresif dan ketidak adilan yang ditemuinya. Proses ini melibatkan dimensi kognitif, emosi dan dinamika kejiwaan, serta dimensi sosial kemasyarakatan (Peter Willis, 2007). Belajar transformatif terjadi apabila seseorang sampai pada suatu tingkat keasadaran tentang konteks dari keyakinan dan asumsi yang dipegangya, kemudian mampu mengkritisi nilai dan asumsinya sendiri, ketika dia mampu mempertimbangkan perspektif alternative, dan dia mampu membuat keputusan yang menghindari perspektif lama, kemudian mengambil tindakan berdasarkan perspektif baru, dan berupaya membawa perspektif baru ke dalam konteks yang lebih luas (Mezirow dalam Nuangcharleem , 2010) . Dalam pendidikan transformative terjadi perubahan yang mendasar terhadap pandangan dunia seseorang melalui dialog dan wacana yang memberi peluang untuk menilai keyakinan, perasaan dan nilainya sendiri Menjadi kritis bukan dalam makna negative berupa kritik, tetapi berarti kemampuan melihat "latar" yang berpengaruh membentuk realita baik secara historis, ekonomi, sosial, politis (Wink, 2000)

Pendidikan transformatif membentuk pribadi yang sadar politik, sejarah, bahkan ideologi melingkari yang realita hidupnya. Pendidikan merupakan proses untuk menggali realita sebagai sesuatu yang terkait dengan sejarah dan perubahan, bukan sebagai kebenaran yang statis, mutlak (Giroux, 1997). Realita adalah "teks" yang harus dimaknai melalui proses "membaca, menginterpretasi, mengkritisi" sinyal-sinyal budaya yang membenttuk, mendominasi, menguasai struktur teks. Dari itu, kerangka berfikir yang membentuk perubahan dalam pendidikan transformatif terletak ada upaya mendekonstruksi hubungan realita (real world) dengan kekuasaan yang dominan, menuju realita baru yang berdaya. Sebagai contoh bagaimana April Baker-Bell (2013) melaporkan studi tentang pembelajaran bahasa Inggris untuk kelompok minoritas dirancang dengan cara yang jauh dari budaya mereka sehingga menimbulkan kegagalan dalam pembelajaran. Untuk keluar dari masalah pembelajaran dimulai dengan proses kritis mendalami konteks sejarah, budaya, dan politik yang terdapat dalam bahasa asli untuk memperkuat kesadaran mereka tentang kemmapuan berbahasa mereka. Kemudian mereka didorong untuk menginterogasi gagasan dominan dari bahasa dan menjadi pelaku aktif dalam pendidikan bahasa mereka, terakhir melakukan kritisi kurikulum pembelajaran bahasa untuk mereka. Contoh lain studi Desyllas \& Sinclair ( 2014), dalam mengembangkan pembelajaran yang bertujuan untuk pembentukan kompetensi pekerja sosial dalam berinteraksi dengan kelompok marginal. Peran mediasi dalam bentuk karya seni sebagai sarana ekspresi siswa mengungkapkan tentang diri (real word) dan hubungan dengan hirarki kekuasaan. Ekspresi seni dan pengungkapan makna merupakan awal pembentukan kesadaran siswa tentang ketidak adilan, kemudian membagun arah baru menempatkan dirinya menjadi pelaku gerakan yang menciptakan realita yang lebih berkeadilan.

Pendidikan multikultural transformatif mengembangkan kompetensi kultural siswa berupa jati diri, dialog, adil melalui proses pembelajaran yang dinamis, terencana, dialogis, dan kritis. Proses ini merupakan antitesis terhadap keonsep pendidikan yang monolog, terpusat dan dominasi guru yang disebut dengan "banking concept"

Paulo Freire (1998) yang mengkritisi konsep pendidikan bank ini dengan mengungkap ciricirinya yaitu: guru adalah pengajar siswa adalah belajar, guru orang yang mengetahui segalanya siswa adalah nol pengetahuan, guru memikirkan siswa objek rencana yang dipikirkan guru, guru berbicara siswa mendengar saja, guru membuat disipilin siswa objeknya, guru melakukan pilihan untuk siswanya, guru merencanakan tindakan untuk siswanya, guru memilihkan program untuk siswa , guru pemegang otoritas pengetahuan dan profesi yang mengekang kebebasan siswa, dan guru adalah subjek pembelajaran dan siswa objeknya. Pendidikan demikian disebut sebagai proses dehumanisasi yang meciptakan siswa yang gagal dalam membangun dirinya menjadi manusia yang bermanfaat. Untuk itu diperlukan pendidikan yang merubah status siswa dari objek menjadi subjek dari tidak 
berdaya menjadi berdaya. Proses ini dimulai dari membangun kesadaran menuju transformasi dari "diri orang lain" menjadi "dirinya sendiri”"

Freire (p 74) mengembangkan konsep pendidikan yang membebaskan siswa dari tekanan sistem yang tidak mendidik yang dikenal dengan "problem posing"-education. Pendidikan merupakan respon terhadap sistem dengan mengangkat kesadaran bahwa mereka berada lingkaran "bukan diri" nya menjadi "dirinya" sendiri. Upaya pendidikan merupakan aktifitas kognisi yang melibatkan proses interaksional guru dan siswa ; mengajar dan belajar (Wink, 2000) sebagai proses pembudayaan interpersonal (Vygotsky, 1978) yang pada tataran tersebut guru dan siswa belajar membangun makna (Bruner, 1990) tentang dirinya, realitanya, sistem nilai, sejarah yang mempengaruhi diri untuk membentuk kesadaran tentang jadi diri (Moeis, 2014).

Bagi Freire konsep pendidikan sebagai aktifitas "kognisi" merupakan negasi terhadap konsep "narasi". Kognisi menempat guru sebagai subjek belajar bersama siswa. Melalui belajar guru dan siswa sama-sama membangun "consciouesness" (kesadaran) tentang realita dengan dialog sebagai pusat pembelajaran. Siswa tidak lagi berperan sebagai "docile body" atau "manusia robot" yang mendegarkan guru bercerita, tetapi siswa adalah co-inverstigator dalam dialog dengan guru untuk menemukan dunianya, serta keterkaitan dunianya dengan konteks yang lebih luas (p 75). Dalam hal ini pendidikan merupakan praktek "pembebasan" dari dominasi yang membatasi pengetahuan; dan pada akhirnya siswa memiliki "kekuatan" untuk mempersepsi secara kritis "way they exsist" in the world with which and in which they find themselves". Siswa menyadari bahwa dunianya bukan lah statis tetapi merupakan proses yang terus berjalan dalam tranformasi.

Bagi Mc Laren (1998) pendidikan (lebih radikal lagi) merupakan proses "self empowerment" dan "sosial transformation" Pendidikan kritis memungkin kan guru, siswa, peneliti memperoleh makna yang lebih tentang sekolah yang berperan sebagai lembaga turut menciptakan ketidak adilan, yang menjadikan masyarakat terkotak-kotak, yang menproduksi nilai dan keistemewaan para elit. Kemudian pendidikan kritis berupaya membangun komitmen baru untuk membentuk belajar dan bertindak yang berdasarkan solidaritas dan mengangkat derajat orang yang terpinggirkan. Karena itu, pendidikan kritis menjadi kan orang memiliki kekuatan dalam diri untuk bangkit dan merubah keterpurukan. Pendidikan adalah proses membangun kekuatan diri dan perubahan sosial.

Pendidikan transformatif memiliki kaitan dengan pendidikan kritis. Perubahan terjadi ketika subjek belajar mengkritisi realitanya. Mengkritisi bukan mengkritik dalam makna negatif tetapi berarti menemukan sesuatu "ketidak adilan" " ketidakpatutan" yang terbentuk dari proses budaya, sejarah, kelembagaan, untuk kemudian membangun "diri yang baru". Pendidikan transformtaif merupakan proses "learning and re-learning" (Wink, 2000). Melalui pendidikan guru dan siswa belajar dalam "lautan" ide-ide baru dan menantang untuk mengitegrasikan ide tersebut kedalam realita. Wink (p27) mengekplorasi bahwa proses pendidikan adalah belajar membuka "keasadaran" tentang ketidak berdayaan untuk bangkit ketaraf berdaya, dan memungkin guru dan siswa memiliki kepercayaan diri tentang pengetahuannya, kemampuannya, dan pengalamannya. Dalam proses membentuk kesadaran guru dan siswa mengerti tentang apa yang terjadi dengan segala bentuk "penamaan", "pengistimewaan" " perangkingan" "pengasingan" yang menyebabkan guru dan siswa kehilangan harga diri, kehilangan kemampuan, kehilangan kemampuan berfikir secara kritis. Keasadaran membuka adanya hegemoni dalam diri dan di luar diri. Proses awal dari pendidikan transformatif adalah "problem posing" mempertanyakan realita dan segala strutur pembentuknya, dan produknya adalah "kesadaran" tentang "ketidakberdayaan diri" dan upaya bangkit membangun "keberdayaan diri" yang baru.

Untuk membandingkan arah pendidikan transformatif ada tiga bentuk model pendidikan yang tercatat sebagai paradigma pendidikan yaitu model transmisi budaya, inkuri sosial, dan inkuiri reflektif (Barr, Bath, and Smith, 1978). Sementara Wink (2000) melihat dalam tiga istilah model transmisi, model generatif dan model transformasi. Bentuk pertama menempatkan pendidikan sebagai terpusat kepada guru dengan siswa pendengar pasif. Model generatif mencakup model inkuiri sosial dan inkuiri reflektif merubah peran guru menjadi fasilitator yang membantu siswa menemukan 
jawaban permasalahan sebagai upaya pengembangan keterampilan berfikir kritis. Kedua bentuk pendekatan dan model menempatkan siswa dalam kelas sebagai subjek belajar. Bentuk ketiga lebih berbeda di mana siswa dan guru membangun pengetahuan dalam kelas dan mengembangkan nya ke dalam komunitas utuk membuat kehidupan menjadi lebih baik. Pendidikan transformatif memfasilitasi guru dan siswa belajar untuk merubah diri dan kehidupannya di tengah komunitas. Oleh karena itu, proses pendidikan berlangsung dalam kesetaraan guru dan siswa sebagai subjek belajar, berlangsung dalam dialog yang konstruktif, (Freire, 1978), berlangsung dalam proses belajar bersama (Wink, 2000) dalam iklim yang bersaudara (Mc laren, 1978), melibatkan emosi dan kognisi dalam interaksi sosial yang aman (Vygotsky, 1978), sehingga guru dan siswa mampu membangun makna yang tentang dirinya yang punya arti bagi kebersamaan dengan orang lain (Bruner, 1978). Pendidikan multikultural transformatif pada akhirnya menghasilkan guru dan siswa yang punya kompetensi kultural: jati diri, dialogis, adil (Moeis, 2014) sehingga mampu yang merubah wajah masyarakat yang bermusuhan menjadi masyarakat yang solid, harmonis dan bersahabat.

Pembahasan

Pendidikan suatu bangsa tidak lepas dari latar budaya, kekhasan, dan sistem nilai bangsa itu sendiri. Oleh karena itu, pengembangan pendidikan multikultural tranformatif bertolak dari karakteristik masyarakat Indonesia (Moeis, 2014). Landasan pertama adalah sistem nilai filosofis bangsa Indonesia yang bersifat religius, yang memberi warna ke dalam niai inti pendidikan multikultural transformatif yaitu: nilai ketaqwaan terhadap Tuhan Yang Maha Esa, nilai tanggungjawab terhadap negara Kesatuan Republik Indonesia, nilai keragaman budaya, nilai supremasi hukum, dan nilai kemanusian yang berkeadilan sosial. Nilai ini dibingkai dalam perspektif lokal dan global sebagai landasan pengkajian yang multidisiplin. Kemudian dikembangkan dalam kerangka pedagogis dalam tiga dimensi ; personal, sosiologis, dan politis. Jika digambarkan dalam diagram akan tampak kerangka konseptual pendidikan multikultural transformatif dalam tiga perspekstif sebagai berikut

\begin{tabular}{|c|c|c|}
\hline Pespektif filosofis & Perspketif keilmuan & Perspektif pedagogik \\
\hline Nilai ketaqwaan terhadap & & \\
\hline Than I allg Malla LSa & Local & - Personal \\
\hline $\begin{array}{l}\text { Nilai Tanggungjawab } \\
\text { terhadap NKRI }\end{array}$ & & $\begin{array}{ll} & \text { (diri) } \\
\text { - } & \text { Sosial }\end{array}$ \\
\hline Nilai Keragaman Budaya & Global & - Politik \\
\hline Nilai supremasi Hukum & & \\
\hline $\begin{array}{l}\text { Nilai kemanusiaan } \\
\text { berkeadilan sosial }\end{array}$ & & \\
\hline
\end{tabular}

Adaptasi dari (Moeis, 2014)

Kompetensi utama yang jadi tujuan pendidikan multikultural transformatif adalah terbentuknya individu yang memiliki jati diri, memiliki kemampuan dialogis yang terbuka, rasional, berwawasan, serta bertindak adil dalam konteks kemanusiaan.

Mengikuti prinsip pembelajaran pendidikan kritis, pendidikan berjalan dalam proses membangun kesadaran kritis guru dan siswa . Dalam hal ini mengikuti Wink (2000) bahwa dalam pendidikan transformatif semangat inkuiri mengarah kepada pencarian makna. Siswa butuh tempat 
yang aman bagi mereka dalam eksplorasi yang berisiko, guru merubah peran dari mengontrol pengetahuan menjadi pengembang proses dimana siswa mengambil kepemilikannya terhadap belajar, dan kemampuan menghadapi resiko dalam memaknai dan menerapkan pengetahuan. Belajar adalah problem posing yang mengikuti pola : to name, to reflect critically, and to act. To name adalah fase melihat masalah, memberi label terhadap masalah, di dalam diri, di dalam kelas di masyarakat semua ada label-label yang dibentuk oleh sistem, seperti masyarakat terasing, masyarakat maju, anak cerdas anak bodoh dst. To reflect critically, berarti seberapa penting pelabelan bagi individu sehingga mempengaruhi dirinya dan cara pandangnya terhadap sesuatu. To act, melihat tindakan yang diperbuat di atas peberian nama, dan mencoba tindakan baru yang lebih adil, berkemanusiaan, dan membawa kerharmonisan

Landasan psikologis pendidikan multikultural transformatif memperhatikan prinsip interaksi sosial yang berjalan dalam kerangka interaksi guru siswa sebagai basis di sekolah. Interaksi ini merupakan ruang sosial sebagai awal pembentukan nilai yang disebut sebagai tataran interpersonal sebagaimana gagasan Vygotsky (Wertsch, 1985). Pembelajaran berlangsung dalam dialog guru dan siswa. Dari tataran interpersonal menuju tataran intra personal yang kemudian membentuk dialog internal sebagai suara batin yang menjadi pengarah prilaku. Proses perpindahan dialog eksternal menjadi internal adalah proses pendidikan yang dijalankan secara konsisten, dan ruang yang aman bagi siswa untuk membangun makna, serta memberi kesempatan untuk mewujudkan komitmen perubahan. Secara praktis penerapan pendidikan multkultural transformative dapat berjalan dalam berbagai pendekatan inovativ yang berpusat pada siswa.

Kesimpulan

Pengembangan disain pendidikan multikultural transformative memerlukan kajian teoritis yang kuat dan definitif. Hal ini disebabkan, pendidikan transformatif melibatkan emosi sekaligus kognisi. Pendidikan ini perlu dijalani dengan suasana atau iklim belajar yang aman untuk mengeksplorasi hal-hal yang "menyakitkan" sebagai penghalang terjadinya dialog dan hubungan yang harmonis serta toleran. Jika pendidikan ini idrancang secara sistematis akan mampu melahirkan subjek belajar yang memiliki jati diri yang kuat, sikap yang terbuka, rasional dan toleran, serta mampu bersikap adil atas dasar kemanusiaan.

Daftar Bacaan

Baker-Bell, April, (2013) "I Never Really Knew the History behind African American Language": Critical Language Pedagogy in an Advanced Placement English Language Arts Class. EQUITY \& EXCELLENCE IN EDUCATION, 46(3), 355-370, 2013

Barr, Robert, and Bath, James, and Shermis, Samuel (1978) The nature of sosial studies . California: an ETC Publication.

Barron, Patrick, and Sharpe , Joanes (2008) local conflict in Post Suharto Indonesia: variation in violence level and form through local news paper. Journal of Asian Studies no 8 (2008) 395423

Beilke, Jayne R. (2005) Whose World Is This? multikultural education Spring 2005

Bruner, Jerome (1990) The Acts of Meaning . Massachusetts: Harvard Press.

Budiwanti, Erni (2003) Mempertahankan Identitas dan toleransi Beragama; Minoritas Muslim di Lombok dan Bali. dalam INIS (ed) . Konflik Komunal di Indonesia Saat ini. Seri INIS:41 Leiden-Jakarta 2003.

Crist. Wilson (2008) Ethno religious Violence in Indonesia : from Soil to God. London and New York: Routledge 
Desyllas, Moshoula Capous \& Sinclair, Allison (, 2014) Zine-Making as a Pedagogical Tool for Transformative Learning in Sosial Work Education . Sosial Work Education, 2014 Vol. 33, No. 3, 296-316) http://dx.doi.org/10.1080/02615479.2013.80519

Freire, Ana Maria and Macedo Donaldo (2000) The Paulo Freire Reader. New York : the CIP group

Khadimally, Seda (2015) Designing Effective Curricula with an Interactive Collaborative Curriculum Design Tool (CCDT) TOJET: The Turkish Online Journal of Educational Technology - July 2015, volume 14 issue 3

Mirza, Nathalie Muller (2011) Civic Education and Intercultural Issues in Switzerland: Psychosocial Dimensions of an Education to "Otherness" Journal of Sosial Science Education @ JSSE 2011 Volume 10, Number 4, 2011, pp. 31-40 ISSN 1618-5293

Nieto, Sonia (1992) Affirming Diversity The Socio political context of Multicutural Education. NY: Longman

Mc Laren, Peter (1998) Life In Schools: An Introduction to Critical Pedgogy in the foundation of Education; NYC: Longman

Moeis, Isnarmi (2014) Pendidikan Multikultural Trasformatif. UNP Press: Padang

Nuangchalerm, Prasart (2010) Promoting Transformative Learning of Preservice Teacher through Contemplative Practices Asian Sosial Science Vol. 6, No. 1 ED507559

Ratnawati, Tri (2003) "Mencari kedamaian di Maluku. Suatu Pendekatan Historis Politis", dalam INIS (ed) . Konflik Komunal di Indonesia Saat ini. Seri INIS:41 Leiden-Jakarta 2003

Ritchie, Scott; Cone, Neporcha; An, Sohyun; and, Bullock, Patricia (2013) .Teacher Education for Sosial Change: Transforming a Content Methods Course Block. Current Issues in Comparative Education 15(2): 63-83

Scheiford, Rheimard (1998) Domestication of Culture . Nation building and ethnic diversity in Indonesia. from http://www.kitlv-journals.nl

Silva, Janelle M , and Day , Regina (2011) Cultivating Agents of Change in Children Theory and Research in Sosial Education Winter 2011, Volume 39, Number 1, pp. 61-91

Tropiano, Carmelo (2008) Paulo Freire, Sosial Change, and the Teaching of Gothic Literature. College Quarterly Spring 2008 - Volume 11 Number 2

Willis, Peter (2007) Transformative pedagogy for sosial capital. Australian Journal of Adult Learning Volume 47, Number 3 november 2007 EJ 797565

Vygotsky, LS (1978) Mind in Society. Massachusetts: Harvard Press

Wertsch, James (1985) Vygotsky and the Sosial Formation of Mind. Cambridge:

Harvard University Press 